\title{
List of tables and case studies
}

Table 2.1 The 1979 devolution referendum in Scotland 10

Table 2.2 The 1997 referendum in Scotland 14

Table 3.1 Scottish Executive ministers October 2000_ 36

Table 3.2 Ministerial committees and working groups 1999-2000 39

Table 3.3 Scottish Executive departments and responsibilities 2000

Table 3.4 Non-departmental public bodies in Scotland $1999 \quad 47$

Table 4.1 Dual-mandate Members of the Scottish Parliament 54

Table 4.2 The Parliament's business managers 59

Table 4.3 Members' motions debated May-July $2000 \quad 61$

Table 4.4 Cross-party groups in the Scottish Parliament, 7 July $2000 \quad 63$

Table 5.1 The committee system of the Scottish Parliament 71

Table 5.2 Meetings of committees 1999-2000 78

Table 5.3 Committee inquiry reports 1999-July 2000 80-1

Table 5.4 Examples of public petitions 1999-2000 85

Table 6.1 Consultations undertaken in pre-legislative scrutiny 93

Table 6.2 MSPs' bills 1999-6 July $2000 \quad 103$

Table 7.1 Pressure group appointments resulting from devolution 1998-2000 123

Table 8.1 Scotland Office staff by administrative group, June $2000 \quad 133$

Table 8.2 Scottish questions topics, July 1999-June $2000 \quad 140-1$

Table 9.1 Concordats between Scottish ministers, the UK government and the Cabinet of the National Assembly of Wales 149-50

Table 9.2 The forward work programme of the European Committee 2000-1 163

Table 10.1 UK general election results in Scotland, 1945-97 167

Table 10.2 Result of the Scottish election 1999 
Table 10.3 National identity and voting in Scotland 177

Table 10.4 Social class and party support $1997 \quad 179$

Table 10.5 Constitutional options and support for independence 181

Table 11.1 National/regional newspaper readership in Scotland, February $2000 \quad 189$

Table 11.2 Partisanship and the press in Scotland 190

Table 11.3 Local newspaper readership in Scotland 1999 192-3

Table 12.1 Scottish local authorities by population 206-7

Table 12.2 Government-supported local authority expenditure 1998-99 210

Table 12.3 Party performance at local elections 1974-99 212

Table 12.4 The independent tradition in

Scottish local government 1974-99 214

Table 12.5 Support for independent candidates at regional elections 215

Table 12.6 Support for independent candidates 1995-9 216

Case study 1 Cross-party group on Borders rail 63

Case study 2 Lobbygate 66

Case study 3 The Justice and Home Affairs Committee 75

Case study 4 The Education, Culture and Sport Committee 76

Case study 5 The Transport and Environment Committee and the telecommunications inquiry 81-2

Case study 6 The policy process of the Scottish Parliament and the Abolition of Feudal Tenure Act (2000) 99-100

Case study 7 The Scottish Council of Voluntary Organisations (SCVO) 116-17

Case study 8 The Scottish Crofters Union (SCU) 118

Case study 9 The Convention of Scottish Local Authorities (COSLA) 119-20

Case study 10 CBI Scotland

Case study 11 The local press and local politicians 194

Case study 12 The Scottish Six and the Newsnight opt-out 195-6

Case study 13 The Daily Record 203

Case study 14 Devolution and Orkney and Shetland 219-20

Case study 15 Local democracy: Stirling Council 222-3 